\title{
ArcheoSciences
}

Revue d'archéométrie

\section{Geophysical prospection of an archaeological site (Grand, France): Characterization of a hydraulic system in a karstic context}

\section{Claire Brinon and Pauline Kessouri}

\section{(2) OpenEdition Journals}

Electronic version

URL: https://journals.openedition.org/archeosciences/1246

DOI: 10.4000/archeosciences. 1246

ISBN: 978-2-7535-1599-4

ISSN: $2104-3728$

Publisher

Presses universitaires de Rennes

\section{Printed version}

Date of publication: 30 October 2009

Number of pages: $39-41$

ISBN: 978-2-7535-0943-6

ISSN: $1960-1360$

\section{Electronic reference}

Claire Brinon and Pauline Kessouri, "Geophysical prospection of an archaeological site (Grand, France): Characterization of a hydraulic system in a karstic context", ArcheoSciences [Online], 33 (suppl.) | 2009, Online since 30 October 2011, connection on 01 February 2022. URL: http:// journals.openedition.org/archeosciences/1246 ; DOI: https://doi.org/10.4000/archeosciences.1246 


\title{
Geophysical prospection of an archaeological site (Grand, France): Characterization of a hydraulic system in a karstic context
}

\author{
Claire Brinon* and Pauline Kessouri*
}

Key words: Geophysics, Grand, Archaeology, Karst, Geology.

The application of geophysical methods for the detection of archaeological features is well-established nowadays. Geophysical surveying is the investigation of shallow subsurface layers with non-destructive tools to obtain quickly information on buried structures without harming these structures. Moreover, excavations, sometimes expensive and disappointing, can frequently be avoided as a result.

The paper is a case study of a Gallo-Roman site and the results of the latest geophysical prospecting. The longterm objective is a spatial description of the town aimed at understanding the links between the location of the ancient site and its geological environment.

The Gallo-Roman site of Grand is located in eastern France (Vosges). It was established in the 1st century AD in land of the Leuci, away from major Roman roads. Sporadic excavations from the 18 th century on have identified the main archaeological structures and given an idea of the spatial organization of the ancient city. The monumental complex includes an amphitheatre, thermal baths, public buildings (one with a mosaic floor), battlements, villas and housing districts (Dechezleprêtre, 2008).

One of the singularities of the site is a developed water supply network from Roman times. In past decades, studies combining both speleological exploration and hydrological/ geophysical surveys have revealed about $15 \mathrm{~km}$ of galleries and their likely convergence at a sinkhole in the very center of the site (Bertaux, 1991).

A series of hypotheses concerning the spatial extent of the town and the hydraulic network can be evaluated based on the results of geophysical investigations.

\section{GEOLOGICAL AND HYDROLOGICAL CONTEXT}

Grand lies on a limestone plateau on the eastern fringe of the Paris Basin, at a point where Middle Oxfordian borders on Late Oxfordian. The stratigraphic sequence is composed of intercalated clay and limestone layers. Karstic features are developed in the carbonate facies in different areas of the plateau. The region is characterized by the absence of permanent surface flow and has for a long time suffered from a lack of water. In fact, underground circulation represents a major part of the flows (Devos, 1996).

Thus, the existence of a natural karstic network supplying water must have determined the siting of the city of Grand. Roman engineers reinforced the rate of discharge by digging artificial conduits connected with the karstic ones, assuring a more regular and dependable water supply (Haguenauer and Deletie, 1991).

* Université Pierre et Marie Curie-Paris 6, UMR 7619 Sisyphe, case 105, 4 place Jussieu, 75252 Paris cedex 05, France. (claire.brinon@upmc.fr) (pauline.kessouri@upmc.fr) 

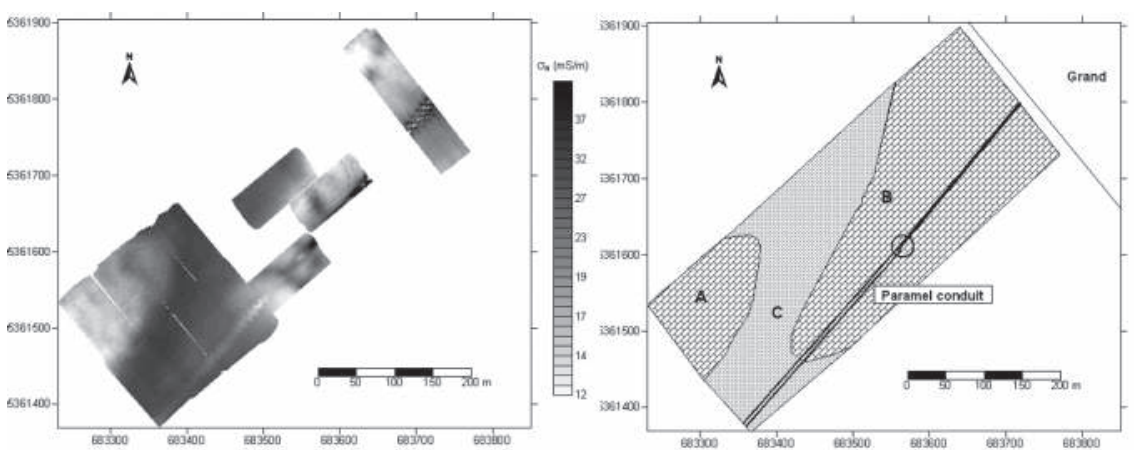

Figure 1: Apparent conductivity map of Paramel area (a) and interpreted map (b). Letters A and B stand for resistive zones, C for the conductive zone. The line represents the conduit; the circle marks the end of the modern pipe.

\section{GEOPHYSICAL PROSPECTION}

The surveys covered several areas to achieve different objectives. On one hand, the geological environment needed to be determined to understand the pattern and the extent of the hydraulic system (karstic/artificial galleries and subsurface Roman aqueducts). On the other hand, areas of potential historical interest, partially excavated by archaeologists, were targeted to obtain new data.

\section{The Paramel case}

The purpose of this survey was double:

- to locate the Paramel conduit under the layer of cultivated soil, knowing that it follows the talweg upstream from the western village;

- to image the lateral sedimentary variations: the border zone between Middle and Late Oxfordian must pass through this zone.

The EM31 was used to measure apparent conductivity, with measurements taken continuously along transects spaced $5 \mathrm{~m}$ apart. Each one was recorded by digital data loggers, then gridded using GPS positioning to make conductivity maps. A fixed frequency of $9.8 \mathrm{kHz}$ and coil spacing of $3.66 \mathrm{~m}$ allowed depth penetration of 5-6 m (MacNeill, 1980; Frischknecht et al., 1991).

The conductivity map (Fig. 1) clearly demonstrates the capabilities of the method. As expected, the metallic pipe in the ancient gallery appears as a high conductive line (50 $\mathrm{mS} / \mathrm{m}$ ) from the northeast (village) to its end (black circle). A linear anomaly with lower conductivity $(15 \mathrm{mS} / \mathrm{m})$, precisely in line with this, reveals the run of the Paramel conduit (built of masonry) to the southwest.

Three distinct areas can be observed on the map: A and B show similar values of conductivity $(12-25 \mathrm{mS} / \mathrm{m})$ and are separated by $\mathrm{C}$, a more conductive anomaly $(30-35 \mathrm{mS} / \mathrm{m})$. In EM data, high conductivity is indicative of sediments rich in clay, organic matter and humidity, whereas low con- ductivity will indicate the presence of calcareous units. This may correspond to the geological border of the Middle/Late Oxfordian limestone.

\section{The 'La Citerne' case}

Remains of a Roman tank in the form of an accumulation of rock fragments can be observed $500 \mathrm{~m}$ south of Grand. As an aqueduct is supposed to join the Sauveuil source and the Grand baths, a preliminary EM analysis was carried out in the vicinity of the tank. Then, additional magnetic surveys were conducted in the zone in order to verify the course taken by this aqueduct.

A G858 Cesium magnetometer was used in gradiometer configuration and took continuous measurements of the geomagnetic field on profiles spaced $1 \mathrm{~m}$ apart. It provided vertical gradient maps.

The conductivity map (Fig. 2) and the magnetic map (Fig. 3) are very coherent. A curvilinear conductive anomaly $(15 \mathrm{mS} / \mathrm{m})$ is observed in the middle of the EM zone, oriented NW-SE and turning to the southwest. It corresponds to a magnetic anomaly at this very point and with the same

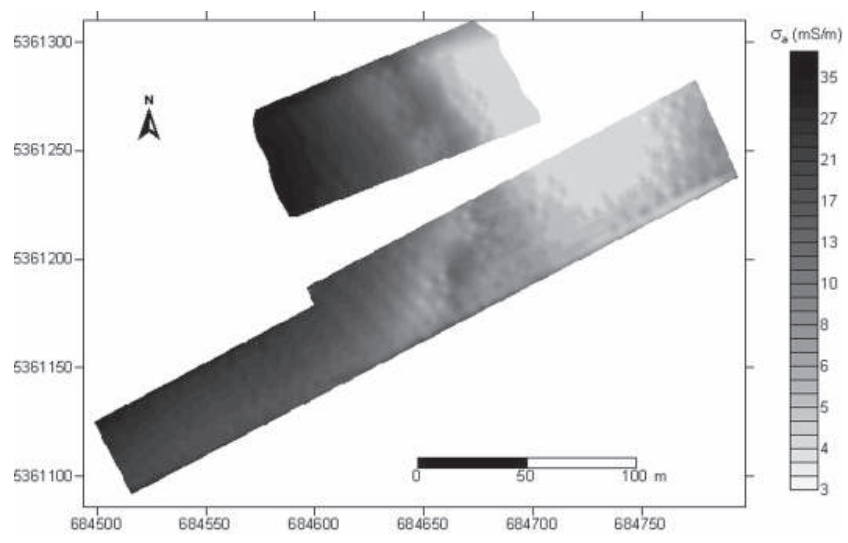

Figure 2: Apparent conductivity map of the 'La Citerne' area next to the Roman tank. 


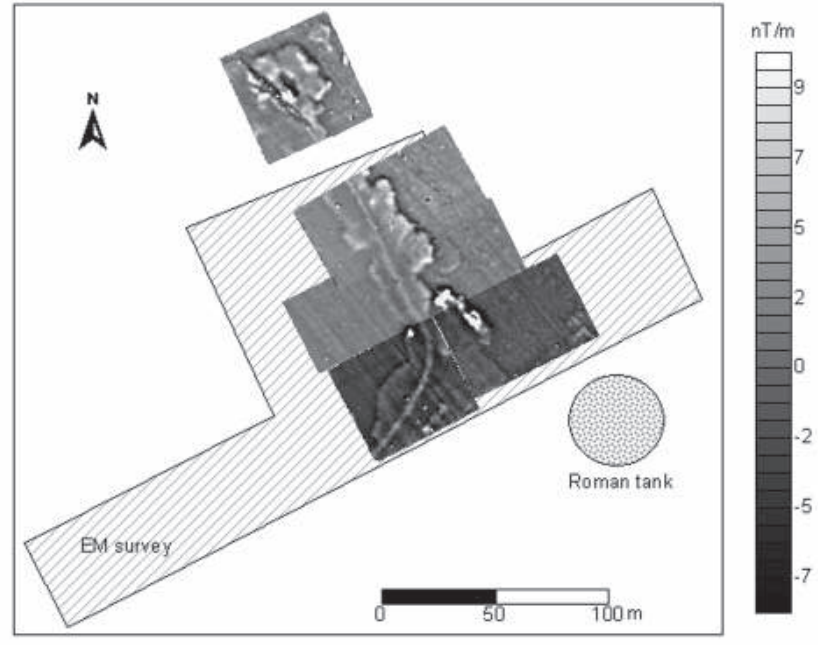

Figure 3: Magnetic field gradient map of the 'La Citerne' area.

orientation. The line of this feature is governed by the topography, passing around a hillock of higher conductivities into a light depression. Further investigations are required to interpret this structure. It is to be identified either as a modern pipe or as the Roman aqueduct.

\section{ConClusion}

The geophysical investigations carried out at the Grand site have mapped many structures related to human activities. The imaging of the Paramel gallery, for instance, proved the efficiency of the method for detection of galleries in this geological context. The objective is to extend the surveys zones and to gain an understanding of the karst network and the hydraulic Roman system. Further geophysical surveys using other methods are needed in order to obtain a comprehensive view of the settling of the Gallo-Roman town on the plateau.

\section{References}

Bertaux, J.-P., 1991. Les galeries souterraines. Dossiers d'archéologie, 162: 28-37.

Dechezlepretre, T., 2008. L'agglomération antique de Grand (Vosges), Rapport de prospection thématique, Conseil général des Vosges.

Devos, A., 1996. Hydrologie et aménagements hydrauliques de la Saulx et de l'Ornain (Lorraine), Thèse de doctorat de l'Université de Metz, 8-28.

Frischinecht, F. C., Labson, V. F., Spies, B. R. and Anderson, W. L., 1991. Profiling methods using small sources. In Nabighian, M. N., (dir.). Electromagnetic methods in applied geophysics 2: Applications, 105-270.

Haguenauer, B., Deletie, P., 1991. Mythe ou réalité la ressource en eau du site. Dossiers d'archéologie, 162: 67-72.

Mc NeILl, J. D., 1980. Electrical terrain conductivity measurement at low induction numbers, Technical Notes TN-6, Geonics Limited. 